Emzar MAKAR ADZE

Batumi Shota Rustaveli State University, Department of Oriental Studies, Georgia

\title{
The Role of Mustafa Kemal Atatürk in Republican Turkey
}

\section{Rola Mustafy Kemala Atatürka w republikańskiej Turcji}

\section{- Abstrakt •}

Republikańska Turcja jest znaczącym krajem o kluczowej pozycji geostrategicznej i wielkiej historycznej przeszłości i teraźniejszości. W ostatnich dziesięcioleciach Turcja rozwinęła swoją gospodarkę do takiego poziomu, że twierdzenie „Turcja wejdzie w XXI wiek jako jeden z najbardziej rozwiniętych krajów" znajduje swoje faktyczne uzasadnienie. Oficjalna doktryna rządu Republiki Turcji, znana jako kemalizm, oparta jest na zasadach zdefiniowanych przez Kemala Atatürka, założyciela Republiki i wielkiego reformatora. Nie można sobie wyobrazić historycznego rozwoju współczesnej Turcji bez Mustafy Kemala Atatürka (1881-1938) właśnie. Zaczął rządzić krajem w najtrudniejszych latach (1918-1923) i jest uważany za założyciela republikańskiej Turcji. Jego fenomen polega na tym, że był jednocześnie żołnierzem, obrońcą religii, mężem stanu i rewolucjonistą.

Słowa kluczowe: Mustafa Kemal Atatürk; laicyzm; republikańska Turcja

\section{- Abstract •}

Republican Turkey is a great country with a crucial geostrategic position, and rich historical past and present. In recent decades, Turkey has developed its economy to such a level that the prediction "Turkey will enter the $21^{\text {st }}$ century as one of the most developed countries", has been realized. The official doctrine of the government of the Republic of Turkey, known as Kemalism, is based on the principles of Kemal Atatürk, the founder of the Republic and a great reformer. Historical development of modern Turkey cannot be imagined without the figure of Mustafa Kemal Atatürk (1881-1938). He began to rule the country in the most difficult years (1918-1923 ) and is considered as the founding father of republican Turkey. The extraordinary impact of Atatürk is attributable to the fact that he was simultaneously a military man, a defender of religion, a statesman, and a revolutionary.

Keywords: Mustafa Kemal Atatürk; laicism; republican Turkey 
Republican Turkey is a great country with a crucial geostrategic position and rich historical past and present. In recent decades, Turkey has developed its economy so much that it did "enter the $21^{\text {st }}$ century as one of the most developed countries".

The official doctrine of the state system of the Turkish Republic, known as Kemalism, is based on the principles introduced by Kemal Atatürk, the founder of the Republic and a great reformer.

Historical development of modern Turkey cannot be imagined without Mustafa Kemal Atatürk (1881-1938). He ruled the country in the most difficult years (1918-1923) and is rightfully considered the founder of republican Turkey. The phenomenon of Atatürk is attributable to the fact that he was simultaneously a military man, a defender of religion, a statesman, and a revolutionary (Makaradze, 2019, p. 295). This extraordinary character has largely influenced the formation of Turkey as a modern country. His principles, known as Kemalism, are the foundation of Turkish republican statehood.

In 1923, Atatürk initiated the creation of the People's Republican Party, whose platform and program became a defining factor for the model of life in the Republic of Turkey.

In May 1931, at the $3^{\text {rd }}$ meeting of the People's Republican Party of Turkey, the closest ally of Kemal Atatürk and then Prime Minister İsmet İnönü articulated six theoretical foundations for all party activities, a defining moment that would later become the bridgehead for the development of republican Turkey. These principles were defined as: republicanism, populism, nationalism, etatism (statism), laicism, and revolutionism (reformism). These foundations, approved at the same Party meeting, were later symbolically incorporated into the Party emblem as 6 white arrows on a red background (red and white being the colors of the national flag of the Republic of Turkey). The party meeting for the first time adopted a platform and programmatic outlines incorporating the aforementioned notions at its core (Bilâ, 1979, p. 82).

These main guiding beacons of the Republican Party have been implemented in Turkey by now. It should be noted though that each of these principles had its own historical evolution, and each of them is also presently going through a very complex and difficult stage of development.

A. Republicanism (cumburiyetçilik): the republican rule system was proclaimed in Turkey in the Constitutions of 1924, 1961, and 1982. Its change or even posing the question of possible change is prohibited by law. Atatürk considered the republican system to be the optimal model of governing a country.

B. Nationalism: Mustafa Kemal attached great importance to this principle, as it helped to maintain the unity of the Turkish nation within the state. 
In connection with this issue, he noted however: "Our nationalism will never be selfish and arrogant” (Atatürkçülük, 1997, p. 28).

At the same time, he strictly distinguished nationalism from Nazism. According to his definition, a nation is built on natural and historical facts: 1. political unity, 2. common language, 3. common homeland, 4. common origin and racial unity, 5. moral foundations and historical past (Kocatürk, 1971, p. 190).

C. Populism (halkçılık): it is close to the previous principle. According to some scholars, true populism, where power belongs to the unified people, naturally stems from nationalism. According to Atatürk, national unity is above all else; Kemalism does not recognize privileges among people, does not agree with the notion of class conflict (Âfet İnan, 1973, p. 35).

D. Statism, or Etatism (devletçilik; from the French word état - the state): this principle has two definitions: in the broad sense, it denotes the policy of economic and sociocultural revival, and in the narrow sense - the leading role of a state in the economy, although it does not mean that everything is governed solely by the state (Kireev, 1991, p. 55).

E. Laicism (lâiklik; from the French word lä̈cité, meaning something secular): it involves separation of religion from the state. The provision defining Islam as state religion contained in the Turkish Constitution of 1924 was repealed on April 10, 1928 by Law No. 1222. Atatürk thus explained his reasoning: "We respect religion, we do not contradict any ideals and schools of thinking. We are just trying our best not to mix religious and state affairs with each other" (Atatürk, 1975, p. 67).

According to the Turkish scholar Berkes, "Laicism played an active role in development of the Western model in Turkey" (Berkes, 1984, p. 128).

F. Revolutionism, or reformism (inkılapçılık): on the one hand, the concept is associated with continuous development of society while on the other hand, it encompasses all of the above principles under the name of Kemalist revolution.

All six foundations of Kemalism are equally important for the republican Turkey, each of them is completely self-standing and inextricably connected to the current economic and political life of the country. Nonetheless, these six principles are closely related to each other and interlinked, forming a cohesive framework.

Without correct understanding of the principles of Kemalism, it is impossible to objectively comprehend the current state of affairs in modern Turkey. These principles are considered to be modeled on Western ideals. However, it should be noted that specific necessary conditions had to emerge to allow for development 
and implementation of these ideas in Turkey. Attempting to free the country from foreign forces, Atatürk and his supporters began to carry out laicist reforms at a scale unprecedented in Islamic countries before, with intention to separate secular and theological governance of the state from each other.

On November 1, 1922, the sultanate and soon after that (on February 29, 1924) also the caliphate were abolished following Atatürk's efforts. In connection with this fact, on the day of next opening of the Grand National Assembly (March 1), Atatürk spoke out against "using Islam as a political weapon" and reminded the deputies and the public of the true purpose of religion.

On March 3, 1924, the Grand National Assembly passed an important law abolishing the caliphate. While this decision was widely supported by the Turkish Grand National Assembly, the Turkish people were accustomed to living in a semi-theocratic regime - they were not receptive to accepting the views of Kemalists without opposition. Supporters of the caliphate declared the Kemalists enemies of religion. While in the Constitution adopted by the Grand National Assembly in 1921 no denomination was recognized as state religion, as a result of constitutional amendment forced by the traditionalists, Islam was thus named in 1923. This provision was also preserved in the Constitution of 1924 and finally abolished for good in 1928; it was the last step in the process of separation of religion from the state in Turkey (Makaradze, 2009, p. 40).

From that moment on, Turkey has been legally and constitutionally a secular state. Abolition of the caliphate was in fact an expression of desire of the "new Turkey" to finally break with its past and create a progressive state modeled on Western democracies.

The principle of laicism was introduced in Turkey within the shortest time of all of the 6 foundations of Kemalism. Atatürk assigned laicism an important role in secular governance of the country, since Islam has for centuries been an ideological factor determining the social development of Turkey. It is interesting to analyze in more detail how Atatürk viewed laicism and how he applied this principle in practice in the Turkish state.

As mentioned above, the direct meaning of "laicism" is "separation of religion from the state" - however, Atatürk's laicism has a more multifaceted, and at the same time, individual meaning. Atatürk stated namely: "The separation of religious ideas from state affairs represents the first and most decisive factor in the progress of the nation" (Atatürkçülük, 1997, p. 43).

According to Kemalists, the principle of "laicism" in republican Turkey ensures spiritual, physical and religious freedom of an individual, inviolability of both theological and secular institutions, and guarantees development of science 
and technology and protection of religious rights, all achieved through separation of religion from the state.

For Mustafa Kemal Atatürk, the underlying principles of functioning of public administration, existing laws and the Constitution should not be based on religious notions, but concepts and ideas stemming from secular development, scientific innovations, modern technologies. Secularization made it possible to establish new and modernize preexisting state institutions, shaping them to take on forms adapted to the modern Turkish world. Atatürk was against abuse of religion in public life. Regarding this issue, he stated: "We derive our inspiration not from heaven or from the unseen world, but directly from life. Our goal is a state in which we Turks live and create our own history" (Atatürkçülük, 1997, p. 47).

Atatürk's expression, "our inspiration not from heaven or from the unseen world", represents one of the foundations of laicism. Mustafa Kemal wanted to govern the state not on the basis of religious principles, but on an enlightened, scientific basis. According to him, "State laicism can be perceived as expressed in a government built on political, economic and social foundations, without intervention of religion".

Atatürk explains the issue of laicism in relation to individual rights as follows: "[...] freedom of religion does not only mean the separation of religion from the state, but the protection of the freedom of religion, prayer and soul of every compatriot" (Armaner, 1997, p. 100).

Such a relationship between laicism and religion clarified the position of spiritual authorities in the life of the country; in such a framework the proper place of religion would be in one's private life. From this point of view, Atatürk's laicism allows religion to fulfill its role in people's lives independently of politics. In short, Kemalist laicism assigns the decision-making powers over state matter to the state authorities, and right of making decisions pertaining to the religious (private) sphere to religious hierarchy - this lies at the core of Atatürk's vision of separating religion from the state.

Kemalists supported the view that if religious authorities would be able to influence only the religious sphere, it would give republican Turkey a real opportunity to move forward and keep developing. In Turkish society, the understanding of the term of course varies, but certain leitmotifs remain distinguishable. Turkish Professor F. Ahmad gives the following definition of laicism: "Laicism is the management of the state not in accordance with religious principles, but in accordance with the laws adopted by the Grand National Assembly of Turkey, elected by the people. According to the principle of laicism, every citizen is free and has the right to perform religious rituals. Propaganda for and against religion is unacceptable" 
(Ahmad, 1976, p. 89). M. Toker stressed in warning in Milliyet: "They want to portray laicism as propaganda of godlessness. All laicist forces in Turkey should be careful and alert to protect laicism, one of the key principles of Kemalism" (Milliyet, 27.07.1986, p. 4, after Cevizoğlu, 1999).

Many scholars of history of Kemalism (such as H. Aykol, A. Akgyul, H. Cevizoğlu, N. Berkesh, V. Kojatyurk, F. Ahmad) attempt to explain how secular authorities at the time of Atatürk were able to quickly ready the society for such civilizational change, paving the way to democratic modernization of the country. This development of events in Turkey is particularly surprising because, unlike in most European countries, laicism in Turkey was not the result of internal evolutionary changes, was not shaped by advanced philosophical ideas influencing the society for centuries. Instead, Kemalists were engaged in purely legislative laicization and Europeanization. Laicism was the main political bet for them, since the continued marriage of state and religion in Turkey could lead to their loss of power in a clash with conservative forces.

\section{Conclusion}

Although the founder of the Turkish Republic Mustafa Kemal Atatürk has established the new Turkey on the principles of secularism and Europeanism, political life in modern Turkey exemplifies the conflict between these principles and so called Turkish religious "traditionalism".

The secularist notion of "laicism" has been somewhat successfully consolidated into the foundations of the modern Turkish society. However, a large part of the Turkish population, especially in the countryside, still persists in its more "traditionalist" views.

96 years have passed since the state governance framework, proposed by Mustafa Kemal in the principles of what is now known as Kemalism, began its journey to implementation. During this time, much has been written and said about this problem - yet, there still remains much to be discussed in the future, as the phenomenon of Atatürk and Kemalism is one of the most interesting elements of the modern Turkish domestic politics. 


\section{References:}

Âfet İnan, A. (1973). Türkiye Cumburiyeti ve Türk Devrimi. Ankara: Başbakanlık Basımevi. Ahmad, F. (1976). Tiirkiye'de cok partiii politikanin aciktamali kronolqjisi (1945-1971). Ankara.

Ahmad, F. (1977). The Turkish Experiment in Democracy (1950-1975). Bolder, Colorado: Westview Press (for the Royal Institute of International Affairs, London).

Ahmet, A. (1995). Dünyanin Değişimi ve Erbakan Devrimi. İstanbul: Doğuş Yayinlari. Armaner, N. (1997). Atatürk - Din ve Laiklik, Atatürkçülük (ikinci kitap). Ankara: Genelkurmay.

Atatürk, K. (1975). Nutuk, c. III. İstanbul: Millî Eğitim Basımevi. Atatürkçülük (1997). Atatürkçü Düşünce Sistemı (üçuncü kitap). İstanbul. Aykol, H. (1996). Türkiye'de săg ve islamci Örgütler. İstanbul: Pelikan Yayınları. Berkes, N. (1984). Teokrasi ve Laiklik. İstanbul: Adam Yayınları.

Bilâ, H. (1979). CHP Tarihı: 1919-1979. Ankara: DMS Doruk Matbaacılık Sanayii. Cevizoğlu, H. (1999). Neden Laiklik: irticai akımlara karşı Kuran’in ve tarihin ışı̆̆ında yeni bir değerlendirme. Ankara: Çığır Stratejik Araştırma Vakfı Yayınları.

Kireev, N.G. (1991). Istoriya Etatizma v Turtsii [The History of Etatism in Turkey]. Moscow: Nauka.

Kocatürk, U. (1971). Atatürk'ün Fikir ve Düşünceleri. Ankara: Edebiyat Yayınevi.

Makaradze, E. (2009). The Role of Mustafa Kemal Atatürk in Republican Turkey. Batumi: Batumi Shota Rustaveli State University (monograph in Georgian).

Makaradze, E. (2019). History of Turkey in 1918-2017 (Reader). Tbilisi (monograph in Georgian). 